\title{
STATUS GIZI PRA HAMIL BERPENGARUH TERHADAP BERAT DAN PANJANG BADAN BAYI LAHIR
}

\author{
Ema Wahyu Ningrum¹, Etika Dewi Cahyaningrum¹ \\ ${ }^{1}$ Prodi Kebidanan D3, STIKES Harapan Bangsa Purwokerto, Jawa Tengah \\ Email : em4wahyuningrum@gmail.com
}

\begin{abstract}
ABSTRAK
Latar Belakang: Status gizi pra hamil yang salah satu indikatornya dengan pengukuran Indeks Massa Tubuh (IMT) secara internasional dianggap sebagai gold standar dan sudah ditetapkan secara baku penambahan berat badan ibu selama kehamilan kedepan. Kurang kepedulian ibu sebelum hamil untuk memeriksakan status gizinya masih sangat kurang, hal ini berakibat tidak terdeteksinya ibu sebelum hamil tersebut mengalami Kekurangan Energi Kronik (KEK) yang kemungkinan besar akan berpengaruh terhadap bayi saat hamil kelak.

Tujuan: Mengetahui pengaruh status gizi pra hamil dengan indikator IMT terhadap berat badan dan panjang badan bayi lahir

Metode: Desain penelitian ini adalah deskriptif korelatiff, dengan pendekatan retrospektif study. Penelitian ini dilakukan Puskesmas Padamara Kabupaten Purbalingga, dengan jumlah sampel sebanyak 30 ibu dan bayi baru lahir. Data status gizi pra hamil, berat badan bayi dan panjang badan bayi diambil dari buku KIA responden dan dianalisis dengan menggunkan uji $\mathrm{R}^{2}$ pada analisis regresi linier sederhana

Hasil: Rata-rata IMT prahamil ibu $22.3 \pm 3.9 \mathrm{~kg} / \mathrm{m}^{2}$ dengan IMT terkecil $17 \mathrm{~kg} / \mathrm{m}^{2}$ dan IMT terbesar $30 \mathrm{~kg} / \mathrm{m}^{2}$. Rata-rata berat badan bayi lahir $2800 \pm 390.8 \mathrm{gram}$ dengan berat badan terendah 2200 gram dan terbesar 3800 gram. Rata-rata panjang badan bayi lahir $48.3 \pm 1,4 \mathrm{~cm}$ dengan panjang badan terpendek $46 \mathrm{~cm}$ dan terpanjang $50 \mathrm{~cm}$. Ada hubungan antara IMT prahamil terhadap berat badan bayi lahir sebesar $\left(r=0.938 ; r^{2}=0.880 ; p<0.01\right)$. Ada hubungan antara IMT prahamil terhadap panjang badan bayi $u$ lahir sebesar $\left(r=0.876 ; r^{2}=0.767 ; p<0.01\right)$

Kesimpulan: Status gizi pra hamil berpengaruh besar terhadap berat badan dan panjang badan bayi lahir. Status gizi pra hamil berpengaruh $88 \%$ terhadap berat badan bayi dan $76 \%$ terhadap panjang badan bayi lahir.
\end{abstract}

Kata Kunci: Status Gizi Pra Hamil; Indeks Massa Tubuh; Berat Bayi Lahir; Panjang Bayi Lahir

\section{PENDAHULUAN}

Status gizi ibu hamil sangat penting untuk tercapainya kesejahteraan ibu dan janin. Seorang ibu yang sehat akan menghasilkan anak yang sehat. Status gizi ibu menjadi faktor penentu utama kualitas sumber daya manusia, terutama sejak 1000 hari pertama kehidupan, pada masa kehamilan sampai usia bayi 2 tahun (Ariyani, 2012). Ibu yang mengalami kekurangan gizi berisiko melahirkan bayi yang kekurangan gizi. Janin yang mengalami malnutrisi sejak dalam kandungan juga berisiko lebih besar untuk lahir stunting (Kurnia, 2013).

Status gizi ibu hamil dapat diukur melalui pertambahan berat badan selama kehamilan, tinggi badan, Indeks Massa Tubuh (IMT) prahamil, dan Lingkar Lengan Atas (LiLA) (Karima, 2012). Pengukuran antopometri tersebut adalah suatu cara untuk mengetahui risiko status gizi Kekurangan Energi Kronik (KEK) wanita usia subur (WUS) dan digunakan untuk memantau perubahan status gizi dalam jangka panjang/kronis. Ambang batas yang digunakan untuk menentukan seorang ibu hamil berisiko KEK adalah $23,5 \mathrm{~cm}$ (Par'i, 2016).

Kejadian KEK merupakan salah satu kasus yang serius karena berdampak jangka 
panjang dan mempengaruhi daur kehidupan. KEK terjadi sebagai akibat dari ketidakseimbangan antara energi yang diasup dan yang dikeluarkan dalam jangka waktu lama. KEK dapat dialami Wanita Usia Subur (WUS) usia 15-45 tahun sejak remaja kemudian berlanjut pada masa kehamilan dan menyusui akibat cadangan energi dan zat gizi yang rendah. Status KEK sebelum hamil mempengaruhi pertumbuhan janin dan menjadi pertimbangan capaian peningkatan berat selama kehamilan.

Hasil penelitian menunjukkan ibu yang mengalami KEK berisiko melahirkan bayi BBLR 4,8 kali lebih besar daripada ibu yang tidak mengalami KEK. Bayi BBLR banyak dihubungkan dengan meningkatnya risiko kesakitan dan kematian bayi, terhambatnya pertumbuhan dan perkembangan kognitif, dan selanjutnya menderita kronik di kemudian hari. BBLR mempunyai risiko kematian neonatal hampir 40 kali lebih besar dibandingkan bayi dengan berat lahir normal, penurunan durasi menyusui, risiko tubuh pendek (stunting) pada masa anak (Nurhayati, 2012).

Penentuan status gizi ibu hamil yang lain yaitu dengan menghitung Indeks Massa Tubuh (IMT) pra hamil. World Health Organization (WHO) menentukan batasan berat badan normal terhadap tinggi badan berdasarkan nilai Indeks Massa Tubuh (IMT)/Body Mass Index (BMI). IMT dihitung berdasarkan berat badan dalam kilogram $(\mathrm{kg})$ dibagi dengan tinggi badan dalam meter kuadrat $\left(\mathrm{m}^{2}\right)$. IMT tidak terkait dengan jenis kelamin, berlaku pada usia dewasa (> 18 tahun) dan tidak sedang hamil (Nurhayati, 2016). IMT tidak dapat diukur saat hamil, karena adanya perubahan berat badan yang terjadi selama kehamilan, sehingga IMT pra hamil digunakan sebagai pedoman status gizi ibu sebelum hamil dan juga menentukan penambahan berat badan secara optimal. Penambahan berat badan direkomendasikan oleh Institute of Medicine (IOM) disesuaikan dengan IMT (Susilojati, 2013).

Anjuran penambahan berat badan hamil berdasarkan IMT pra hamil menurut IOM adalah: IMT $<18,5 \mathrm{~kg} / \mathrm{m}^{2}$ penambahan berat badan 28-40 pound (setaran dengan 12,6-18 kg), IMT 18,5-24,9 kg/m² dengan penambahan berat badan 25-35 pound (setaran dengan 11,25-15,75kg), IMT 25-29,9 $\mathrm{kg} / \mathrm{m}^{2}$ dengan penambahan berat badan 15-25 pound (setaran dengan $6,75-11,25 \mathrm{~kg}$ ) dan IMT $30 \mathrm{~kg} / \mathrm{m}^{2}$ dengan penambahan berat badan 11-20 pound (setaran dengan 4,95-9kg) (Ariyani, 2013).

Berdasarkan penelitian Erika dalam Yongki (2012) di Vietnam mendapatkan hasil bahwa ibu yang memiliki IMT rendah, pada umumnya memiliki risiko melahirkan bayi dengan BBLR untuk kehamilan cukup bulan, terutama ketika jumlah kenaikan berat badan kehamilan ibu $<10 \mathrm{~kg}$. Berdasarkan penelitian yang dilakukan oleh Yokoyama Sugimoto dalam Yongki (2012), bahwa panjang badan bayi lahir paling dipengaruhi oleh usia kehamilan dan IMT. Wanita yang memiliki IMT<26,0 kg/m² akan memiliki bayi dengan panjang badan $1,5 \mathrm{~cm}$ lebih daripada wanita yang memiliki IMT $<19,8 \mathrm{~kg} / \mathrm{m}^{2}$, begitu pula penelitian di Rumah Sakit Rajavithi, Thailand diperoleh data bahwa ibu kelompok underweight cenderung melahirkan bayi BBLR dan prematur, ibu kelompok obesitas melahirkan bayi makrosomia/bayi besar 
(Saereeporncharenkul, 2011).

Berdasar data Riskesdas tahun 2013, prevalensi KEK ibu hamil usia 15-49 tahun adalah $24,2 \%$ dan wanita tidak hamil usia 15-49 tahun sebesar $20,8 \%$. Hasil tersebut menunjukkan bahwa prevalensi risiko KEK pada ibu hamil masih tinggi. Adapun di kabupaten Purbalingga tahun 2016, ditemukan sejumlah 9,35\% ibu hamil KEK. Data ini pun menunjukkan prevalensi risiko KEK pada ibu hamil masih tinggi. Tujuan dari penelitian ini adalah untuk melihat seberapa besar pengaruh status gizi pra hamil dengan idikator IMT terhadap berat badan dan panjang badan bayi baru lahir.

\section{METODE}

Penelitian ini merupakan jenis penelitian deskriptif korelatiff, yaitu studi yang membahas tentang derajat hubungan antara variabel-variabel, ukuran yang dipakai untuk mengetahui derajad hubungan terutama data kuantitatif dinamakan koefisien korelasi (Arifin, 2011). Desain yang digunakan adalah retrospektif study yaitu desain penelitian berupa pengamatan terhadap peristiwa-peristiwa yang yang telah terjadibertujuan untuk mencarifaktor yang berhubungan dengan penyebab Budiarto. (2004)

Penelitian ini dilakukan Puskesmas Padamara Kabupaten Purbalingga, dengan jumlah sampel sebanyak 30 ibu dan bayi baru. Penelitian ini menggunkan data sekunder berupa data status gizi pra hamil yaitu data IMT ibu, berat badan bayi dan panjang badan bayi yang diambil dari buku KIA responden. Data dianalisis dengan menggunkan uji $\mathrm{R}^{2}$ pada regresi linier sederhana.

\section{HASIL}

Hasil penelitian menunjukkan rata-rata IMT prahamil ibu $22.3 \pm 3.9 \mathrm{~kg} / \mathrm{m}^{2}$ dengan IMT terkecil $17 \mathrm{~kg} / \mathrm{m}^{2}$ dan IMT terbesar $30 \mathrm{~kg} / \mathrm{m}^{2}$. Rata-rata berat badan bayi lahir $2800 \pm 390.8 \mathrm{gram}$ dengan berat badan terendah 2200 gram dan terbesar 3800 gram. Rata-rata panjang badan bayi lahir $48.3 \pm 1,4 \mathrm{~cm}$ dengan panjang badan terpendek $46 \mathrm{~cm}$ dan terpanjang $50 \mathrm{~cm}$. (Tabel 1).

Ada hubungan yang sangat kuat dan signifikan antara IMT ibu pra hamil dengan berat badan bayi lahir $(r=0.876 ; p<0.01)$. Hasil analisis pengaruh didapatkan nilai $r^{2}$ sebesar 0.880 , yang artinya status gizi ibu pra hamil memiliki berpengaruh sebesar $88 \%$ terhadap berat badan bayi baru lahir. Ada hubungan yang sangat kuat dan signifikan antara IMT ibu pra hamil dengan panjang badan bayi lahir $(r=0.876 ; \quad p<0.01)$. Hasil analisis pengaruh didapatkan nilai $r^{2}$ sebesar 0.767 , yang artinya status gizi ibu pra hamil memiliki berpengaruh sebesar $76 \%$ terhadap panjang badan bayi baru lahir. (Tabel 2).

\section{PEMBAHASAN}

Status gizi ibu menentukan kualitas outcome yang dihasilkan. lbu yang mengalami kekurangan gizi berisiko melahirkan bayi yang kekurangan gizi. Janin yang mengalami malnutrisi sejak dalam kandungan juga berisiko lebih besar untuk lahir stunting (Kurnia, 2013).

Status gizi ibu hamil dapat diukur melalui pertambahan berat badan selama kehamilan, tinggi badan, Indeks Massa Tubuh (IMT) prahamil, dan Lingkar Lengan Atas (LiLA) (Karima, 2012). 
E W Ningrum, E D Cahyaningrum | Status Gizi Pra Hamil Berpengaruh Terhadap Berat dan Panjang Badan Bayi Lahir

Tabel 1. Analisis Deskriptif IMT Prahamil, Berat Badan dan Panjang Badan Bayi Lahir

\begin{tabular}{lccc}
\hline Variabel & Mean \pm SD & Median & Min-Max \\
\hline IMT pra hamil & $22.3 \pm 3.9$ & 21.7 & $17-30$ \\
Berat bayi lahir & $2800 \pm 390.8$ & 2800 & $2200-3800$ \\
Panjang bayi lahir & $48.3 \pm 1.4$ & 48 & $46-50$ \\
\hline
\end{tabular}

Tabel 2. Analisis Hubungan dan Pengaruh IMT Prahamil dengan Berat Badan dan Panjang Badan Bayi Lahir

\begin{tabular}{lccc}
\hline Variabel & $\mathbf{R}$ & $\mathbf{R}^{2}$ & $\mathbf{p}$-value \\
\hline Berat bayi lahir & 0.938 & 0.880 & 0.0001 \\
Panjang bayi lahir & 0.876 & 0.767 & 0.0001 \\
\hline R & &
\end{tabular}

$R$ Square Test

IMT prahamil ibu dianggap dapat menunjukkan kualitas gizi ibu pada masa sebelum hamil sekaligus juga menunjukkan ketersediaan gizi dalam jaringan tubuh ibu sebelum hamil (Achadi et al, 2008) yang akan memberikan dampak pada kesehatan ibu dan pertumbuhan janin selama dalam kandungan.

Garn dan Pesick dalam Claudia (2012) menuliskan dalam penelitian yang dilakukan terhadap 44.725 ibu hamil di Amerika bahwa IMT merupakan penilaian status gizi ibu sebelum memasuki masa kehamilan yang lebih tepat dalam memprediksi berat lahir bayi yang akan dilahirkan dibandingkan dengan pengukuran berat badan ibu pra-kehamilan saja. Selain itu disebutkan oleh Nohr et al. dalam Claudia (2012) bahwa risiko melahirkan bayi yang kecil terhadap umur gestasi menurun bersamaan dengan adanya peningkatan IMT sebelum memasuki masa kehamilan. Selain itu, penelitian ini juga menyebutkan bahwa IMT sebelum masa kehamilan merupakan penelitian yang paling tepat untuk memprediksi kualitas bayi yang dilahirkan.

Pada penelitian ini menunjukkan bahwa IMT pra hamil memiliki hubungan yang bermakna dengan berat lahir bayi $(p$ value $=$ $0,0001)$ dan memiliki hubungan sangat kuat $(r=0,938)$. IMT prahamil menyumbang $88 \%$ sebesar $\left(r^{2}=0,880\right)$ terhadap berat badan bayi baru lahir, sedangkan pengukuran berat lahir bayi lainnya dipengaruhi variabel lain.

Hasil penelitian ini didukung oleh penelitian Claudia (2012) yang menunjukkan bahwa ibu dengan IMT kurang dari $18,5 \mathrm{~kg} / \mathrm{m}^{2}$ memiliki risiko melahirkan bayi dengan berat lahir kurang dari 3000 gram 2,8 kali lebih besar dibandingkan ibu dengan IMT 18,5 $\mathrm{kg} / \mathrm{m}^{2}$ atau lebih, dengan nilai kebermaknaan hubungan antara IMT prahamil ibu dan berat lahir bayi $(p=0,011)$ dan IMT prahamil ibu didapatkan memberikan prediksi sebesar $22,6 \%$ terhadap berat lahir bayi.

Selain itu, pada penelitian ini menunjukkan bahwa IMT pra hamil menyumbang terhadap panjang badan bayi baru lahir sebesar 76,7\% $\quad\left(r^{2}=0,767\right)$, sedangkan sisanya dipengaruhi variabel lain. Hubungan IMT prahamil memiliki hubungan yang bermakna dengan panjang lahir bayi ( $p$ value $=0,0001)$ dan kuat $(r=0,876)$. serta berpola positif yang berarti semakin besar IMT prahamil maka akan semakin besar juga panjang lahir bayi yang dilahirkan bayi tersebut,

Penelitian ini didukung oleh penelitian Nohr et al. (2008), Neggers dan Goldenberg 
(2003) dan Ronnenberg et al. (2003) terkait dengan IMT prahamil dan panjang lahir bayi. Berdasarkan penelitian-penelitian tersebut, didapatkan bahwa IMT prahamil ibu merupakan faktor yang dapat memprediksi panjang lahir bayi. Hasil penelitian Claudia (2012) juga menunjukkan bahwa terdapat hubungan antara IMT prahamil ibu dengan panjang lahir bayi $(p=0,047)$. Didapatkan bahwa ibu dengan IMT prahamil kurang dari $18,5 \mathrm{~kg} / \mathrm{m}^{2}$ memiliki risiko 2,2 kali lebih besar melahirkan bayi dengan panjang lahir kurang dari $48 \mathrm{~cm}$ dibandingkan ibu dengan IMT prahamil 18,5 kg/m² atau lebih (Claudia, 2012).

IMT prahamil merupakan indikator status gizi ibu hamil yang diukur pada saat pra hamil dengan mengukur berat badan prahamil dengan tinggi badan ibu. Institute of Medicine (1990) telah menetapkan rekomendasi pertambahan berat badan ibu selama kehamilan, atau yang disebut juga sebagai selisih berat badan ibu sebelum melahirkan dengan berat badan ibu sebelum memasuki masa kehamilan. Rekomendasi pertambahan berat badan selama masa kehamilan ini dikaitkan dengan kualitas bayi yang dilahirkan dilihat melalui berat dan panjang lahir (Institute of Medicine, 1990). Pertambahan berat badan selama masa kehamilan ini ditetapkan rekomendasinya dengan turut memperhitungkan IMT prahamil ibu, rekomendasi pertambahan berat badan berbeda untuk ibu dengan kategori IMT berbeda (Claudia, 2012)..

IMT ibu sebelum memasuki masa kehamilan merupakan salah satu indikator status gizi yang perlu diperhatikan. Penilaian status gizi ibu melalui perhitungan IMT dapat menunjukkan kualitas gizi ibu pada masa sebelumnya yang dapat memberikan dampak kepada kesehatan ibu dan janin selama masa kehamilan dan kualitas bayi yang akan dilahirkan, IMT menunjukkan persediaan gizi dalam jaringan tubuh ibu (Achadi, et al., 2008) Oleh karenanya, ditetapkanlah IMT yang dianggap cukup dan baik dimiliki ibu sebelum memasuki masa kehamilan, yaitu IMT yang berada pada kategori status gizi normal (Institute of Medicine, 1990), atau berada di antara 18,5 hingga $25 \mathrm{~kg} / \mathrm{m}^{2}$ (Yongki, 2012). Dituliskan dalam buku Nutrition During Pregnancy and Lactation (Institute of Medicine, 1990) bahwa keadaan obesitas (IMT jauh di atas standar normal) dapat meningkatkan risiko terjadinya berbagai penyakit kronik dan komplikasi kehamilan. Sedangkan, IMT di bawah standar normal dapat meningkatkan risiko melahirkan bayi dengan berat lahir rendah (Claudia, 2012).

\section{KESIMPULAN DAN SARAN}

Penelitian ini memperoleh kesimpulan bahwa status gizi pra hamil berhubungan erat dan memiliki pengaruh yang besar terhadap berat badan dan panjang badan bayi baru lahir. Status gizi pra hamil berpengaruh $88 \%$ terhadap berat badan bayi dan $76 \%$ terhadap panjang badan bayi baru lahir. Diharapkan pada para ibu agar merencanakan kehamilan dengan baik, salah satunya dengan memperhatikan status gizi pra hamil dengan cara pengukuran IMT, sehingga bila terjadi KEK dapat diketahui dan dilakukan penatalaksanaan secara dini, karena akan berpengaruh terhadap berat dan panjang badan bayi yang akan di kandungnya. 


\section{DAFTAR PUSTAKA}

Achadi, Endang L. et al. (2008). Pengukuran status gizi ibu hamil dan ibu menyusui dengan metoda antropometri. Nutrire Diaita, 1, 49-76.

Arifin, Zaenal. (2011). Penelitian Pendidikan: Metode dan Paradigma Baru. Bandung: PT Remaja Rosdakarya

Ariyani, Diny Eva, Endang Laksmining Achadi, and Anies Irawati. (2012). Validitas Lingkar Lengan Atas Mendeteksi Risiko Kekurangan Energi Kronis pada Wanita Indonesia. Kesmas: National Public Health Journal, 7(2), 83-90.

Budiarto. (2004). Metodologi Penelitian Kedokteran, Sebuah Pengantar. Jakarta: EGC

Claudia, Debtarsie K. (2012). Hubungan Status Gizi ibu dan faktor Lain dengan Berat dan panjang Lahir Bayi di Rumah Sakit Sint Carolus Jakarta Bulan Juli-September 2011. Skrpsi. Universitas Indonesia

Irawati, A., \& Rachmalina, R. (2013). Indeks Massa Tubuh Ibu PRA Hamil Sebagai Faktor Risiko Pertambahan Berat Badan Ibu Hamil Di Kelurahan Kebon Kelapa Dan Ciwaringin, Kecamatan Bogor Tengah, Kota Bogor. Jurnal Ekologi Kesehatan, 12(2), 117-127.

Karima, Khaula, Endang L Achadi. (2012). Status Gizi Ibu dan Berat Badan Lahir Bayi. Kesmas: National Public Health Journal, 7(3), 111-119.

Kementerian Kesehatan RI. (2013). Riset Kesehatan Dasar 2013. http://depkes.go.id/downloads/riskesdas20 13/Hasil\%20Riskesdas\%202013.pdf

Kurnia, Yustiana and Nuryanto Nuryanto. (2014). Perbedaan Panjang Badan Bayi Baru Lahir Antara Ibu Hamil KEK dan Tidak KEK. Disertasi. Diponegoro University,

Nurhayati, Eka. (2016). Indeks Massa Tubuh (IMT) Pra Hamil dan Kenaikan Berat Badan Ibu Selama hamil Berhubungan dengan Berat Badan Bayi Lahir. Jurnal Ners dan Kebidanan Indonesia 4(1), 1-5

Par'i, Holil Muhammad. (2016). Penilai Status Gizi dilengkapi Proses Asuhan Gizi Terstandar. Jakarta: EGC

Saereeporncharenkul, Kasem. (2011). Correlation of BMI to pregnancy outcomes in Thai women delivered in Rajavithi Hospital. J Med Assoc Thai 94. Suppl 2: S52-S58.

Susilojati, Rr. D, and Handayani, S. (2013).
Hubungan Pertambahan Berat Badan Ibu Saat Hamil Berdasarkan Indeks Massa Tubuh dengan Berat Badan Bayi Baru Lahir. Jurnal Kebidanan, 5(2),

Yongki, Hardiansyah, Gulardi, Marhamah. (2009). Status Gizi Awal Kehamilan dan Pertambahan Berat Badan lbu Hamil Kaitannya Dengan BBLR. Jurnal Gizi dan Pangan, 4(1), 8-12 